\title{
Reading and Remembering the Anthropologist James F. Weiner
}

\author{
INTRODUCTION
}

\author{
Aletta Biersack \\ University of Oregon \\ Laurence Goldman \\ The University of Queensland \\ Katie Glaskin \\ The University of Western Australia
}

This retrospective addresses the anthropological writings — both academic and applied — of James F. Weiner (1950-2020). Weiner would take the name Jaimie Pearl Bloom and begin living openly as a transgender woman in 2016. Jaimie was proudly transgender and worked in Melbourne (where she had moved in 2018) to support LGBTIQ rights and transgender issues. She co-founded the Bent Twig Alliance to address the needs of elderly members of the community.

We are informed by several people who knew her in her last years that Jaimie accepted being referred to as 'James' or 'Jimmy' in commentary on her anthropological work. Largely because the contributors to this retrospective engage with James F. Weiner, the author of multiple anthropological texts dating from 1984 to 2017, many (but not all) have chosen to write about and refer to her as 'Jimmy'. No disrespect is shown or intended to Jaimie Pearl Bloom, whom most of us did not have the opportunity to meet. And so it is to 'Jimmy' that we now turn.

James F. Weiner — author, teacher, researcher, and consultant - earned his master's degree in anthropology at Northwestern University, where he was influenced by Roy Wagner (see Leach's contribution). He went on, briefly, to the University of Chicago but finished his 
doctoral degree at the Australian National University (1984). His dissertation on the Foi of Papua New Guinea (see Young's contribution) would be published as The Heart of the Pearl Shell (1988), a year that also saw the publication of his edited collection Mountain Papuans. The Empty Place (1991), The Lost Drum (1995), and Tree Leaf Talk (2001) would soon follow. Weiner's contribution to Songs of the Empty Place (co-authored with Don Niles) was written by 1995 but would not be published until 2015. A raft of peer-reviewed articles on a wide range of topics, several of which were reprinted in important anthologies, cemented Weiner's reputation. During these early years he would teach at ANU, the University of Manchester (1990-1994), and the University of Adelaide (1994-1999). A mere thirteen years after receiving his doctorate, Weiner, an American, would be named Fellow of the Academy of the Social Sciences in Australia.

From the commencement of his career, Weiner's topics of choice, explored largely with reference to the Foi, were myth, poetry, music, space and topography, and philosophy and aesthetics, contributions to which several authors here, students and colleagues of his at the University of Manchester (Ingold, Strathern, Crook and Leach), discuss. Yet over the course of Weiner's career, this repertoire of interests and expertise would widen significantly. Although a Melanesianist by training, Weiner was also interested in Indigenous Australia. Alan Rumsey, Weiner's colleague at ANU, shared Weiner's fascination with both cultural contexts and collaborated with him first to organize an international conference at ANU in 1997, and then to co-author and co-edit two well-received conference volumes: Emplaced Myth (2001) and Mining and Indigenous Lifeworlds in Australia and Papua New Guinea (2001, 2004) (see Rumsey's contribution).

The title of the conference was "From Myths to Minerals," a title that augured Weiner's eventual shift in focus and positionality (Weiner 2002). Beginning in 1995, with his first 
article on the Hindmarsh Island Bridge Affair, through to his retirement, Weiner pursued both his Australian and New Guinea interests as an engaged anthropologist and consultant wanting to do 'something that mattered' (see Merlan's contribution). In this work, Weiner was as sensitive to the politics and dynamics of (as he termed it) the 'conjunctural' or 'intercultural' fields of colonialism and globalisation as he was to Aboriginal heritage and native title rights, topics he pursued together with Katie Glaskin in Customary Land Tenure $\&$ Registration in Australia and Papua New Guinea (2007) and Custom: Indigenous Tradition and Law in the 21st Century (2006) and in numerous native title cases (see Glaskin's contribution). Concomitantly, his consultancy work in Papua New Guinea cast a critical eye on the organisational infrastructure ("incorporated land groups" or ILGs) developed by the Government of PNG to enable landowners to register as decision-making entities for land resource management and to enjoy benefits derived from use of that land.

By the time of his retirement in 2015 (with some consultancy work thereafter), Weiner's principal interests had shifted towards politico-legal anthropology, applied anthropology, and colonialism, globalisation and development studies — fields to which he made substantial contributions (see Rumsey's, Merlan's, Glaskin's, and Goldman's discussions). This combination of interests prepared him well to participate in training a new generation of anthropologists wanting to instrumentalise their knowledge in critical ways. During the three inaugural years of the University of St Andrew's Centre for Pacific Studies (2008-2010), Weiner held a prestigious Leverhulme Trust Visiting Professorship. Under the rubric of 'dialogues between anthropology, customary law and statute law in resource development contexts', Weiner gave postgraduate lectures, offered research seminars, and participated in a series of interdisciplinary workshops contributing towards a new course on indigenous peoples and resource extraction. 
Sadly, Jaimie died in Melbourne on 14 June 20 from complications following surgery

related to Crohn's disease, which she had lived with since adolescence. Remarkably, this did not keep her from fatherhood, extensive fieldwork, prolific writing, teaching (often to enthralled audiences) and consultancy and advocacy work — that is, from everything she thought mattered.

\title{
AMONG THE FOI OF HEGESO: LETTERS FROM THE FIELD
}

\author{
Michael W. Young \\ The Australian National University
}

\begin{abstract}
After a few fits and starts Jimmy Weiner became an exemplary fieldworker. He was frank about his early mistakes and apologetic about what he called his 'indiscretions'. He was also a dutiful correspondent who scrupulously submitted his quarterly reports on time. His letters were well composed, informative, and neatly typed in single space. I replied as best I could in similarly witty vein to amuse him as he so often did me. Between 5 September 1979 and 9 January 1981, he sent me about twenty letters, most of them between 1000-2000 words. My replies were shorter and fewer than half that number. ${ }^{1}$
\end{abstract}

Alluding to the Vietnam War, a running joke in our correspondence was the rigorous training in fieldwork method Jimmy received at the University of Chicago.

The anthropology department is run like Special Forces Training Camp. They teach you ruthlessness as a matter of course, and always to go for the jugular. Like paratrooper training, they pitted us against each other to watch the blood flow; those who survived (most didn't) learned there was a reason for it: to make sure that no matter where we go, we'll be spotted as U. of Chicago products: "Fearless men who jump and die," our forearms tattooed with the words "Born to KILL". (26 September 1979)

He was certainly unafraid to appear tough and make enemies of his white colleagues. 
After four months in the field, he admitted to being 'as tactless as hell in Mendi' (the headquarters of Southern Highlands Province) and 'not too well liked' by people on the Research Committee whose monthly meetings he was obliged to attend.

I'm already tired of the little charade the Australian-English ex-pats play to keep their distance from the locals. In the Provincial Research Committee there is not one Papua New Guinean. In other words, research priorities are decided by whites only. (ibid.)

Having experienced four years of PNG Independence, Foi dissatisfaction with unmet promises had become evident. They were unhappy about the provincial government's general neglect and the lack of any 'development', especially its failure to build a road link to the Highlands Highway. A more muted grievance was the lack of material benefits from the long presence of the Asia Pacific Christian Mission. There was concern about a steep decline in the pig population, welcomed by the missionary but deplored by Foi big men, whose ceremonial pig-kills had been curtailed. 'The people may be Christian, but they are fearful Christians', Jimmy wrote, and 'when they pray for forgiveness they are praying to the missionary and not to whatever grotesque parody of a God he has introduced'. Jimmy took pains to explain his own Judaism to his Foi friends, "partly as an introduction to the idea that there are many types of religion and many types of Christianity' (ibid.).

He had much to learn about Foi notions of reciprocity, and after five months in the field, he recorded a bewildering setback, to him a 'major crisis'.

I returned from Mendi laden with gifts and it gave me great joy to distribute them to those people who had been especially friendly and helpful. I was therefore quite upset when they all presented me with "bills", demands for cash for the work they had done. Suddenly the friends I had been counting on appeared in a different light. I felt ashamed, but I think they realize that I don't know what the proper manner of compensation is. I thought I'd eminently repaid everyone, and now they're all asking me for cash. I'll have to revise my estimates of Foi generosity.... But when something like this happens, I feel even more depressed about my lack of progress in the language, and I'm ashamed to say that I'm not putting enough effort into it. (9 November 1979)

Kinship was Jimmy's forte, and the complexities of Foi social organization would 
become the central topic of his dissertation. He meticulously recorded details of marriages past and present to unravel the intricate patterns of bridewealth and death payments, and he soon discovered that patrilineal ideology in group formation was less important to Foi for daily cooperation than affinal ties: in short, alliance trumped agnation. He devoted many weeks to the collection of statistics to determine how widely networks based on bridewealth ramified throughout the four-longhouse neighbourhood in which his village of Hegeso is situated.

He had been asked by the Mendi Research Committee to report on nutrition, and what better way to begin than to practice 'participant observation' and plant his own garden? 'I have deliberately planted it in the true Highlands style, with plenty of kaukau [sweet potato] mounds and lots of different beans'. He discovered that there were fewer young men nowadays to clear new garden land: 'the smarter ones' had gone to work in the towns. Old gardens were planted too frequently, and the poor quality of the soils reduced their yield. 'The people's diet now is about $95 \%$ sago, and the bellies of young children are distended: these beautiful children with smiles like sunshine, already malnourished and susceptible to disease!' (26 September 1979)

When the pig ceremonies were flourishing, meat was more continuously available, and game too, because there were ritual incentives for men to hunt more than they do now. With the decline in amounts of wealth (as measured in pigs and shell kina) one would expect the bride price to go down. But it remains high, too high for young men to afford any wife but an older or divorced woman. It's the old men who can afford to buy the young ones. No need to say what has happened to the birth-rate. (ibid.)

Asked what he was doing in the way of participant observation, Jimmy's reply

appeared to challenge the value of received anthropological wisdom:

I could go on for pages musing over its theoretical implications. I am all for it in practice: I sleep in the men's longhouse most nights, eat with them nearly every day, work in the gardens with them and even tried pounding sago. I built my own bush house (with help) and paddle my own canoe. I help entertain visitors by fetching food and water. However, I believe that participant observation is like trying to pat your head and rub your belly at the same time. Knowing how to do something is not the same thing as understanding it.... In December I will get decorated and sing and dance with the other 
Hegeso men. I also speak pretty good Foi now. So big deal! None of these things by themselves have yielded valuable insights of the kind I've gotten by careful

interviewing. (26 October 1980)

Marie Reay 'grumbled' that he seemed to believe anthropology was concerned chiefly with models. He protested that he 'always considered fieldwork to be chiefly concerned with people: a slight difference. I suspect that deep down I'm a frustrated "hard" scientist' (9 November 1979). Almost a year later, I also had reason to warn him of relying too heavily on Roy Wagner's 'obviation model'2 for analysing the Foi myths he was busily recording, transcribing, and translating. 'I'm just playing around with some ideas, or as we Yanks say, shooting it up the flagpole to see if anyone salutes' (26 October 1980).

But his commitment to Wagner was unshakable, and I was proven correct when two of his three thesis examiners criticized his thoroughgoing 'obviation' analyses without giving due consideration to alternative methods. A related point was made by two examiners who found his ethnographic descriptions lacking in 'agency'; the Foi remain anonymous. 'We are told repeatedly what "the Foi" do or believe or say ... but there is little in people's own words, and little attention to who the people are' (Examiner's Report, December 1983).

Jimmy's letter of 26 October 1980 ended with a handwritten plea: 'If Ronald Reagan is elected, can I stay in Australia, please?' Indeed, for most of the next forty years he did.

\section{MEDIATIONS}

Marilyn Strathern

University of Cambridge

Anyone glancing at what Jimmy published over a too short span will appreciate what scholarship lies there. In reading through a voluminous file of correspondence (personal, collegial, administrative), beginning in 1984 — when I was at ANU with the gender relations group in which Jimmy participated ${ }^{3}$ - I am further struck by the intensity of Jimmy's 
commitment. It got Jimmy into trouble sometimes, but we should add that the years at Chicago, preceding student days at ANU, also helped form one of the most incisive minds of that generation.

When Don Tuzin reviewed The Empty Place alongside an account of first contact in Highlands PNG, he imagined how a no-nonsense, embattled explorer might have greeted 'aesthetics' and 'poetics' used as descriptors of the mentality (Tuzin's phrasing) behind the eyes glowering from around war shields. Indeed. But an important qualification is that Jimmy described poetry as women's, not men's, distinctive compositions; the latter's job was, simply, to perform them. For central to Foi sociality was the place of what Jimmy called 'intersexual mediation'. Jimmy's proposal to the gender relations group in 1984, that male and female valences mobilized distinctions not restricted to men's and women's roles, was accompanied by a list of three papers already written on gender (eventually published as the articles noted below), and especially the newly examined $\mathrm{PhD}$ thesis, on which The Heart of the Pearl Shell would be based. Of all Jimmy's work, I pull on a thread that draws out the at once trenchant and delicate way in which it addressed gender matters.

Many of the participants in the ANU gender relations group had been inspired by the rising concerns of feminist anthropology. In a letter to me half a decade later, and in a quite different context (critical comments on something I'd written), Jimmy wrote: 'I guess what my big beef is that I don't think feminism has re-invented a thing. It's repositioned an already existing discourse on consciousness and power to its own purpose'. Mediating his material through certain currents of philosophical and psychoanalytic thought, Jimmy's anthropological outlook was already thickened, so to speak, by other genres, and his working through 'gender relations' had its own rationale, and indeed name.

The Heart of the Pearl Shell accords cosmological weight to 'intersexual mediation': relations between male and female and between affines encompass one another as 'the most 
pervasive conceptual foundations of Foi sociality' (1988:4). Male-female relations are a way of phrasing central ideologies regarding life and death. Men control the flow of life-giving energy (the shell's 'heart' is the movement men give it in their procreative re-positioning of kin); above all, men are distinguished by the responsibility they take for separating dead from living and — in a perpetual drama of differentiation — themselves from women. The latter is intersexual mediation, it is argued, not gender role, for everything turns on what is made not just of relations between men and women but also of relating as such. Jimmy's other genre here is the relatively self-contained corpus of Foi myth, in which differences emerge as analogous to one another against the need (of morality, sociality) to sustain them.

Equally, it seems, a further other genre was Lévi-Strauss's structuralism, whose semantic analysis of myth Jimmy complemented with a tropic one (1988:155). In a statement of interests compiled in Manchester about 1993, Jimmy described a whole quartet of books, at a moment when two were published and two being written, in terms of their contrastive theories of discourse - their other genres (my phrase). Just as the initial monograph addressed Lévi-Strauss and Durkheim, in Jimmy’s words The Empty Place (1991) appealed to the non-Cartesian thinkers Merleau-Ponty, Heidegger and Cassirer, while The Lost Drum (1995) would explore implications of Lacanian psychoanalytic theory for analyzing Australian and Papuan myth. Some of the fourth became Tree Leaf Talk (2001) and proposed drawing on Nietzsche and Adorno as well as Heidegger.

The Lost Drum, subtitled The Myth of Sexuality, deploys Lacan's reformulations of Freud to return to Foi mythology, imagining objects such as drums as though they were myths, and myths as drum-like objects, thereby offering a relation through which to address the bodily manifestation of men's and women's capacities. Such particular embodiments are but instances of 'any perception which calls forth its own external bounding' (1995:17). However, let us dwell somewhat longer on The Empty Place, where diverse 'non-Cartesian' 
philosophers are evoked rather generally to counter the 'bias' that separates thought and perception from activity and the body from its surroundings (1991:152). It is necessary to be reminded of these writers, or else one might misunderstand the emphasis Jimmy puts on the embodied and sensual part that Foi women play here. In this book, women also create another 'other genre': memorial song poems.

As an inversion of the divide between creativity and maintenance in mundane subsistence, Foi women are acknowledged as creative poets, whose compositions men faithfully render in public singing. Crucial is the way women's poetry is composed as part of their rhythmic work of sago pounding and shredding, absent men being invoked as subjects of the memorialization. Thus, Jimmy observes, through affective statements women poetically reconstruct an inhabited, spatial world of male activity.

... Foi men objectify the definitional aspects of Foi words. Women, by contrast, are the image makers ... [for] they repair the deficiencies of the Foi language by restoring the experiential and apperceptive qualities to communication. Men make magic, the most crudely instrumental use to which metaphor can be put; women make poetry, which restores trope to its existential foundation (1991:11, emphasis omitted).

Needless to say, mediation is crucial: these dimensions of discursive life are as necessary to each other as, Jimmy says, the distinction between metaphor and image is fundamental to language function.

A passage that particularly evokes the intensity with which Jimmy's thinking was suffused with the rendering of other genres begins as follows:

Through dreams men gain access to metaphor [which they decode]; women, in their reverie over dead kinsmen, create images. Metaphor embodies the striving of men in a static, atemporal formula; poetic image embodies the historical nexus of human attachment and loss. (1991:119)

I only knew Jaimie Bloom as James Weiner and refer to her as Jimmy.

\section{THINKING IN THE WORLD}




\section{University of Aberdeen}

It all seems so long ago! Thirty years have passed since Jimmy Weiner arrived in Manchester, as a new appointee in the Department of Social Anthropology, where he was to remain for a little over four years. That's when I got to know him. Our respective backgrounds and interests could hardly have been more different: he, with his deep immersion both in Melanesian ethnography and in the philosophical currents of Western humanism; me with my interests in the peoples of the circumpolar North, and a resolve to integrate the lessons of social anthropology with the sciences of ecology and evolutionary biology. Perhaps we were brought together by a shared feeling of being fish out of water. My ecological and evolutionary proclivities had been met in the Department with an apathy bordering on hostility, and no one else was remotely interested in the North. Nor, until Jimmy arrived, was anyone especially interested in philosophy. In those days, however, Melanesianists ruled the anthropological roost, and with one of their leading figures heading the Department, it all felt rather close for comfort. Echoing to the footsteps of Roy Wagner (1981), they would make out that there were Melanesians and there were Euro-Americans, and that was it! Everyone else was left out, including their ethnographers.

I could not stomach this idea of 'Euro-American'. To me, as a British-born Europhile, America was, and still is, incomprehensible. I could never feel at home there. But for Jimmy, as an American, it was Britain - or, more particularly, England - that he found incomprehensible. He would later write in his book Tree Leaf Talk (2001a), referring to his fieldwork in the Foi village of Hegeso in Papua New Guinea, that 'as an American who has lived in England for four and a half years, I experienced more alienation, bafflement, and notat-homeness in England than I ever did in Hegeso village in two and a half years' (2001a:54). So we were both a bit lost, in our different ways. For me personally, those years from 1990 to 1994, during which Jimmy and I were Departmental colleagues, were a time of intellectual 
upheaval. My efforts to synthesise social anthropology with human ecology and evolutionary theory had collapsed, and I was having to start all over again. I had drawn inspiration from developmental biology and ecological psychology, but something else was missing. I needed a philosophical alternative to cognitivism. Eventually I found my way to first Heidegger and then Merleau-Ponty. And that was precisely when Jimmy found his way to Manchester!

Among the courses Jimmy taught was one, for advanced undergraduate and postgraduate students, with the super-boring title Issues in Language and Culture. The lectures, however, were anything but boring. In one year I attended the course myself, entirely for my own benefit. Sitting at the back of the class, I recall my relief that, unlike the students, I would not have to write essays or take an examination to test my understanding. Much of it, indeed, went over my head. Hardest to grasp was the heavy-duty analytic philosophy of language. Maybe it would have been easier had I actually read the works of the many famous philosophers - Quine, Davidson, Frege, Grice, Ryle and many others — to whom Jimmy would refer with such facility. If this was not a little intimidating for me, imagine how it felt for the students! Yet even if his audience understood only a fraction of what was going on, they were transfixed by the sheer intellectual energy that Jimmy brought to his lectures. There was a sense of being present as the very foundations of anthropology were being rewritten. What the students didn't know, however, was that every year, despite the unchanged title, Jimmy completely rewrote his lectures to reflect the progress of his own work.

Jimmy and I had converged in our opposition to cultural constructionism, to the idea that reality is known only by its representations, fashioned from the raw materials of sensation by minds ready-furnished with concepts. I vividly remember how, in one of his lectures, Jimmy demolished the thesis of Lakoff and Johnson in their Metaphors We Live By (1980), much in vogue at the time, namely that everyday reality is structured by concepts drawn from bodily 
experience. Absolutely not! As Jimmy would go on to show, in Tree Leaf Talk, 'both the "experiential" and the "conceptual" are necessary and reciprocal existential components of a total life condition' (2001a:48). Yet for all that, our respective positions remained far apart. For Jimmy, the task of human being was to configure a world from the protean grounds of earthly existence. Or is that what it was for the Foi? Or for Heidegger? It was often hard to tell. At any rate, Jimmy took from Heidegger the idea that whatever is not configured, or disclosed, remains therefore hidden or concealed. Disclosure and concealment were to be seen as two sides of the same coin of Being, and for Jimmy as for Heidegger, in the tension between them lay the wellspring of social life.

I could never accept this. Heidegger's unforgivable error, in my view (Ingold 2011:147), was to have compared the emplaced space of human dwelling to a clearing, and the horizon — on the hither side of which things come into presence — to the edge of the woods, beyond which they are lost to the forest. The error was unforgivable since it led directly to the idea of Lebensraum, of a lifeworld whose very openness was founded upon a principle of closure. The rest is history. Jimmy realised the danger and was careful not to go there. But I could not agree to his definition of ecology, in Tree Leaf Talk (2001:164), as the study of relations with that which lies beyond or exceeds the human pale, but still exerts its influence. For in my understanding it is a constitutive quality of life, human or nonhuman, that it always exceeds itself, crossing no horizons since horizons move as life does. An ecology of life, then, would be driven not by disclosure and concealment, but by growth and renewal. I was with Bergson, a philosopher whose work I began reading in the early 1980s, when it was deeply unfashionable. I had been as taken with Bergson as Jimmy was with Heidegger. Why the difference?

At the heart of Bergson's philosophy is not being but life, the becoming of things. It is a vitalism that chimes with the experience of northern circumpolar peoples. Under the intimate 
immensity of northern skies, with their boundless horizons, there is no place for concealment, nor conversely for disclosure. There are only moments of incipience. Life here inhabits the cusp, wherein things are ever on the point of revealing themselves for what they are. But in the dense and luxuriant tropical forests of Papua New Guinea, things appear from behind the trees, only to disappear again. The spaces of human dwelling are perpetually vulnerable to being overwhelmed by the powers of vegetative growth. Bergson, of course, never went North, nor Heidegger to the tropics; nevertheless one can understand the appeal of a philosophy that resonates with environmental experience. This is not to argue that environment determines thought, but merely to acknowledge that as the milieu gets under the skin of the mind, it inflects our thinking from the inside. Like our interlocutors, wherever they may live, we do our thinking in the world, and the world is in us as we think. That's why anthropologists make better philosophers than philosophers themselves. We have the legacy of Jimmy's work to prove it.

\author{
ART AND MYTH \\ James Leach \\ Aix Marseille Université, CNRS, EHESS - CREDO (UMR 7308) \\ The University of Western Australia
}

On my desk I have the text of an email written by James F. Weiner in 1993. It is laminated, back to back, accompanied by another piece of text that was also important to me at that time: a list of medicines for emergency administration in the Tropics. This was part of my survival kit for fieldwork in Papua New Guinea. The inclusion of the email shows the influence of and reassurance I felt in being close to Weiner and his ideas. Jimmy's email was a complaint against those who undertake fieldwork with a 'mound of electronic equipment' 
in which they 'glory': 'surely no more naive and innocent indictment of the failure of cognitive anthropology'. As a hopeful novice this was heady stuff. Weiner continued:

Although I would not deny that technology embodies and facilitates a relational world, I would definitely be skeptical of rendering the lived speech, the full word and the communal lifeworld of a non-western community solely in its terms. [These] machines for modern ethnography serve as displacements for the emotional attachments one hopes to experience in the field and out of which one fashions a sense of the displacements of meaning and history which constitute the subject matter of an ethnographic account.

Weiner was a voracious scholar, reading widely and deeply. His texts draw upon and extend complex philosophies, psychoanalytic theory and linguistic anthropology. Yet the coherence of his oeuvre is compelling. He focussed on how human symbolisation precipitates its own grounds, and thus (has to) counter-invent its foundations, hiding the very processes by which it comes to have effect. Weiner explicitly credited the work of Roy Wagner for this position, which he developed and then moved beyond to startling effect.

In The Invention of Culture (1981), Wagner proposed a theory of human culture that attends to metaphor and the play of convention and invention in metaphoric usage. He argued that metaphor relies on the conventional referents of words and images. Conventional meaning is the sedimented effect of previous metaphoric usages. Metaphor is central to human culture, he argued, bringing conventional elements into new alignments in ways that recontextualise these elements, shifting and refreshing their meaning. At the same time that metaphor creates new meaning it relies on and subtly 'obviates' previous conventional meaning. Invention always 'precipitates' convention as its background.

Wagner insists that culture is a dual process in which that which is consciously invented relies, for its motivation and meaning, on what is already 'given' (what is 'conventionalised'). He elaborated the example of the 'western' mode of symbolisation, which operates with (the convention of) an already differentiated world: humans are different from animals, elements have properties, etc. These are what previous language use has sedimented as 'convention'. In this mode, humans cannot change the given world (nature) but 
can classify its elements, use them, organise them, etc. 'Nature' is thus made to appear as the background to, and the motivation for, human action. This mode is termed a 'collectivising' symbolisation. Against this, he described a different mode that he associated with Melanesia, one which assumes the world is undifferentiated flows and connections and the work of human beings is to make differences and distinctions appear in order for (human) life to be possible (distinctions between humans and animals, or the genders, or between life and death, for example, result from human actions). This is a 'differentiating' mode. Whether working in collectivising or differentiating mode, convention and invention are always in play as each 'motivates' the other.

Weiner's work was aimed at exploring a differentiating mode for the Foi and reflecting from that understanding more widely on the processes of human culture and meaning. His writings on the Foi thus represent major contributions to anthropological and social theory, critiquing 'constructionism' and advancing a powerful perspective on myth and art.

Weiner repeatedly asked us as students and colleagues to consider the following question: 'What if the foundations of human worlds were myth and art instead of production and intention?' Weiner showed how the Foi lifeworld is not about constructing a human world out of nature's raw materials but is about intervening to direct flows of analogy and substance: that which is already 'given' in their mode of symbolisation. It was in this context that the centrality of myth and art emerged: "myths are revealed precisely because of what they hide: the creation of morality and human convention out of the particular actions and dilemmas of archetypal characters' (Weiner 1988:14).

Developing Wagner's distinction between collectivising and differentiating symbolic modes, Weiner argued that a structuralist analysis of myth is a perfect vehicle for elaborating collectivising symbolisations: that is, for metaphors and tropes that draw like things together because of their properties. However, structural analysis 
cannot ... explain how the different elements that comprise its basic analogies became differentiated in the first place, preferring to see difference itself as "self-evident." But I am interested in the way that metaphor creates, rather than merely reflects, reality. (ibid.:11-12, my emphasis)

This interest was closely tied to his assertion that for the Foi, 'differentiation is convention' (ibid.:10), and it lay at the heart of his confrontation with what he described as today's dominant anthropological theory and methodology.

Constructionism, simply put, avows that the cultural significance people make of the world is the way that the world achieves an effect and reality for them. The emphasis is on the ability and tendency of human beings actively to fashion a world of meaning and relevance for themselves. (Weiner 2001a:xiii)

In a heated debate with Faye Ginsburg, he claimed this led to the 'aestheticisation' of social life — that is, understanding all culture to be about representing aspects of itself to itself (Weiner 1997a). Instead, myth revealed the 'lineaments' of a lived human world, what is counter-invented as resistance to intention, or that which goes beyond human meaning. The theme was further elaborated and explored in his experiments with Lacanian theory, articulating links in psychoanalysis, phenomenology, linguistic anthropology and the Foi ethnography (Weiner 1995).

Weiner's emotional engagement with the Foi is apparent in his description of their sung poetry and the paths and places (Weiner 1991), flows and deliberate interruptions (Weiner 1988:9), that their myth and sung poetry reflect. He saw these as the core correspondences and analogies with which they live: female and male, life and death. But these things were not pre-given material from which to make a meaningful world. In their very fundamentalness they were already and only part of human meaning making. A Foi life, a Foi death, is just that. The theme here is still the counter-invented, revealed in art, the play of figure and ground, the precipitation of meanings other than human intentions or productions. And in this 
he found a further ally through his reading of Heidegger (Weiner 1992, 1993, 2001a). If art reveals the limits of human knowledge as an aspect of its construction, then its inverse for Weiner (and Heidegger) is technology. Technology conceals in a double way. For it works upon a world that is apparently already given and available for human appropriation, and in doing so, conceals its very activity of naturalising that world.

When finishing his email on 'machines for modern ethnography', Weiner wrote, 'we have reposited a metaphysic into such machines that impinges upon the description of a community for which such a metaphysic is inapplicable'.

I knew Jimmy as a courageous person — courageous in his fieldwork, in his honesty and willingness to make scholarly life (at which he obviously excelled) constantly challenging. Through Weiner's work, a profound legacy for anthropology is inscribed and reinscribed. Art and myth, in this anthropology, cannot be about representing social relationality at all, but must be about revealing its inverse, the 'ground' against which relationality produces its forms. There is much still to be considered and learned following this legacy.

Acknowledging the transition from Jimmy Weiner to Jaimie Bloom (whom I never met), I follow Marilyn Strathern's lead and invite people to (re)read 'Jimmy' as 'Jaimie' and 'his' as 'her'.

\author{
WHAT CANNOT BE SAID MUST BE ACTED OUT \\ Tony Crook \\ University of St Andrews
}

To my shame, I hadn't heard of, much less read, James F. Weiner until he opened an office door at the University of Manchester in early 1992. I was there for an interview for a coveted place on the doctoral programme. Before a handshake was offered and before the door was closed, relations were obviated: 'Hi, I'm Jimmy Weiner and this is Professor Strathern. 
Marilyn is about to move to Cambridge. Do you want to continue this interview?' Tea was offered, it emerged that Marilyn wasn't leaving for another year, and Jimmy had made quite an impression - his grasp of Melanesian linguistics and philosophy was all too evident as was the agility required to keep up with his ideas. Although I subsequently transferred to Cambridge after Jimmy moved to Adelaide in the mid-1990s, his influence on my work endures and was refreshed when he held a Leverhulme Trust Visiting Professorship at the Centre for Pacific Studies at the University of St Andrews from 2008-2010, its inaugural years.

Jimmy Weiner loved language — loved what it could and couldn't say; loved the predicaments created for the fieldworker, analyst, writer and human being; and loved to play with words, not least in his animated sparring during departmental seminars. This serious play brought the pleasures of meanings participating in and escaping each other, and of the mutual interplay of subjectivities amongst speakers. Supervisions with Jimmy entailed a dizzying Zen training and took the form of Koan — unsolvable enigmas, ideas to puzzle and ponder, language instrumentalised to strike a tangent on established thought, much as 'a myth has to strike off the surface of language at a tangent in order to impinge upon it' (Weiner 1995:96). Jimmy was a voracious and clever reader of literature and was deeply moved by music — reminding me that Lévi-Strauss credited Richard Wagner with the structural analysis of myth.

This love of language was Jimmy's intellectual passion too, developing an 'anthropology of language' (in preference to 'linguistic anthropology' [Weiner 1995:33]), beginning with highly original ethnographic expositions of Foi poetry in The Empty Place (1991; see also Weiner and Niles 2015). This distinctive synthesis is evident, for example, in arguing that speaking (and language as phenomenologically conceived) should be approached as an 'activity like other bodily activities' (1991:14), and that '[w] hat is seen to lie beyond 
language must be included in a description of it' (1995:178, original emphasis). This synthesis also involves reading the animated participation of anthropological analysis in the Foi lifeworld, and vice versa. That is to say, Jimmy's thinking was always animated through ethnographic and Foi analyses of a lifeworld conceived in metaphoric and relational terms, and in which the positions of analyst and interlocutor were approached as analogous orientations rather than as fundamentally distinct existential conditions (see Crook 2007:6773).

The Empty Place brilliantly illustrates and analyses Foi poetic forms of song and spell through examples of movement and ontological orientation and demonstrates how these are inscribed in all bodily activity. This is thoroughgoing: movements within bodies of procreative substances differ like those of men and women in their productive activities and indeed the roles of image in metaphoric usage. Jimmy argues that the Foi contrast gendered 'approaches to signification and linguistic embodiment themselves' (1991:27), comprising 'distinct male and female existential conditions' (ibid.:11, emphasis removed). Foi women produce a continuing flow of menstrual procreative substance, just as their obedobora sago songs 'reveal the flow of analogy between discursive domains' (ibid.:29). Foi men fix the flowing blood in their wife's womb to form a foetus (ibid.:6, 26), much as they 'cut off the flow of meaning rather than enhance it' (ibid.:29). These contrasting bodily manifestations of analogic flow become obvious when Foi men sub-divide and rearrange women's obedobora compositions and perform them 'more than twice as fast' (ibid.:156) during their own fire-lit longhouse sorohabora dances, which turn 'women's poems into a total kinesthetic image' (ibid.:153).

In keeping with Jimmy’s argument about Foi men's ‘moral necessity to cut, channel and redirect such flows for socially and cosmologically important purposes' (ibid.:7), I sent him the ethnographic experiment below suggesting that sorohabora performances act out and 
mimic the motions of the sago process as a technique to amplify and channel the quality and flow of sago flour:

Foi women construct a processing trough from two sago fronds - 'raised at one end, and at the other, a palm-spathe vessel catches the liquid that flows down it' (ibid.:120). Once sago pith is placed in the trough, a woman 'pours water over it, and then loosens the starch granules by beating the pith with a four-foot-long hardwood stick' before 'kneading and squeezing the moistened pith' as the whitish and yellow-orange milky solution of 'starch in suspension accumulates at the bottom of the palm-spathe vessel' (ibid.). One obedobora composition sings of how sunlight reflects in different ways off the surface of the Mubi River (ibid.:125), suggestive of the colouration of white froth and the coloured liquid suspension of sago in the trough (ibid.:126). This enchanting light play of white and warm colours is also displayed by Foi men during the torch-lit performance of sorohabora, when the longhouse becomes 'the venue for the initial stages of sexual flirtation and attraction' (ibid.:151). Women watch from the sides as dancers move down the corridor in song rounds, pounding their bows - ' $[\mathrm{t}]$ he torches glint off their bodies in flashes of oily red-orange light, and there is a vibration of white cockatoo feathers as they march ...' (ibid.:152). A sorohabora might culminate with 'a young man, beautifully decorated, being handed a bamboo tube of drinking water by an admiring young woman during a break in his all-night singing and dancing' (ibid.:151) — just as in other circumstances a woman might add water to the sago trough. Here, the lines of the women's verses are distributed in suspension among performers bobbing in agitation and flowing in beaten-out pulsations down the corridor - the men embodying and redirecting these flows for unspoken ends. The aesthetics appear too striking to be arbitrary and are in keeping with the thrust of Jimmy's own exposition, though not in so many words. 
This modest analytical vignette seemed then (and seems now) to manifest exactly what Jimmy was teaching us. However, rather than a revelatory 'bursting open of a seed pod and the subsequent discharge of its contents' (Weiner 1995:4), this experimental tangent turned out to be a popped balloon: 'Look, that's just a literary interpretation; I can assure you that no Foi person has ever made or expressed that connection' (pers. comm.). Of course, as a doctoral student at the time, this rather intriguing, enigmatic and crushing response seemed more than a little contradictory of Jimmy's advocacy of an anthropology of language and ritual in which '[w] hat cannot be said must be acted out' (ibid.:178).

Looking back, I now prefer to take away the confirmation of Jimmy's consummate qualities as a fieldworker - for, of course, he was speaking in the person of a Foi person and thus exemplifying his own insight that 'each person's subjectivity may at any time escape his or her power, may in fact participate in and constitute other persons' (1995:xvi). Perhaps not all enigmas are unsolvable? This brief reflection enacts a personal acknowledgement of Jimmy's fire, friendship and influence; it constitutes a compliment to the highest achievements of a serious and honest anthropology and the accomplishment of living a life open to life.

\section{FROM MYTH TO MINERALS}

Alan Rumsey

The Australian National University

I first met Jimmy Weiner in 1977, at a party in Chicago attended mainly by $\mathrm{PhD}$ students in anthropology. The only thing I remember Jimmy talking about there was a dream he had had, in which the dramatis personae were himself, Nancy Munn, from whom he had been taking a course, and the Wawilak sisters, who feature in a key myth-ritual complex in northeast Arnhem Land, on which Munn had published an important study (Munn 1969). Some of the 
more Freudian aspects of the dream were bizarre and milked by Jimmy for their full comic potential, but his admiration for Nancy Munn and fascination with Australian Aboriginal mythology and cosmology were obvious.

I did not see Jimmy again until 1982, by which time we had both moved to Australia and he was writing his PhD thesis on myths of the Foi people in the Southern Highlands Province of Papua New Guinea. My anthropological interaction with him took a new turn after he returned to Australia from Manchester in 1994, and we in effect restarted the conversation that had been opened at the party all those years before in Chicago, about the world-making powers of Australian 'travelling dreaming' figures such as the Wawilak sisters. I had just published a new take on that kind of narrative (Rumsey 1994), and Jimmy highlighted those same world-making powers in his new book The Lost Drum, in which he developed explicit comparisons between Australian myths and ones told by the Foi and other groups in southern New Guinea (Weiner 1995:54-91). In that connection Jimmy made me aware of Roy Wagner's (1972:20) discussion of parallels between the so-called Papuan hero tales and Australian myths of travelling-dreaming figures - a comparison which, we discovered, had recently been expanded upon by Bruce Knauft in his book South Coast New Guinea Cultures (1993).

At around the same time, following closely upon Jimmy's move back to Australia, he began to do new field research on the cosmology and politics of Foi and Fasu people's experience of the extractive industry in the Kutubu Oil Project Area, and published the related article 'The Origin of Petroleum at Lake Kutubu' (Weiner 1994). I had developed a similar interest, in part from my fieldwork in Western Australia, where I was on the scene when Aboriginal traditional owners, out of cosmological concerns, had tried unsuccessfully to block an oil drilling operation at Noonkanbah in 1980 (Kolig 1987) and also from my joint 
fieldwork with Francesca Merlan in the Northern Territory with Jawoyn traditional owners, who successfully blocked a proposed new mine at Coronation Hill in 1991 (Merlan 1991). Stimulated in part by these kinds of resonances between our work in Papua New Guinea and Aboriginal Australia, on the model of then-recent cross-regional conferences focused on comparisons between Melanesia and Africa (Lambek and Strathern 1998) and between Melanesia and Amazonia (Gregor and Tuzin 2001), we decided to convene a conference focussed on comparisons between Aboriginal Australia and Melanesia, with particular reference to indigenous cosmologies and the impact of multinational resource extraction on them in both regions. With funding from the Wenner-Gren Foundation, the conference was held at Australian National University over four days in July 1997, with participants from Australia, Europe, the US and Papua New Guinea. The conference resulted in two published volumes, one of which focussed mainly on cosmologies and their grounding in mythically inscribed landscape (Rumsey and Weiner [eds.] 2001a) and the other on mining and the ways in which those cosmologies informed people's experience of it and were affected by it (Rumsey and Weiner [eds.] 2001b).

Here are some of our main findings regarding indigenous cosmologies.

1. While it has long been recognized by anthropologists and others that a key aspect of Australian Aboriginal lifeworlds is their grounding in mythically inscribed landscape, this is also true of many areas in Melanesia, where it has not been as fully recognized.

2. In many parts of New Guinea, as in Australia, a key aspect of the world-making activities of the mythic heroes is that they did not stay put but moved across the land or sea, creating named places out of their bodies (or parts of them), places that are thereby linked to each other in series.

3. Important aspects of people's social and personal identity are linked to the mythically inscribed places through ancestral and other connections to them. 
4. In addition to the overall similarities that Wagner had noticed between Australian travelling-dreaming myths and the Papuan hero tales of southern New Guinea, there are detailed correspondences between those myths and ones in the nearby western Torres Straits Islands that link up in a continuous series with myths told in the eastern Torres Straits Islands and mainland Australia, extending to Wik Munkan on the Western Cape York Peninsula and Mamu, which is more than 500 kilometres down the coast of eastern Queensland.

Regarding the impact of mining on indigenous lifeworlds, a central axis of contrast at the conference opposed Australia as a 'settled' continent, where there was wholesale dispossession of Aboriginal land, and Papua New Guinea, where over 90 percent of the land surface has never been alienated. But, less obviously, we found that there were some important continuities, owing to: 1) a shared form of land title (largely unheard of outside of Australia and PNG) in which the state retains ownership of underground resources; 2) the manner in which western law has been used in both countries to define and codify customary land tenure; and 3) similarities in the ways that social identities both in Aboriginal Australia and in parts of New Guinea have been understood to be grounded in landscape, as summarised above. So, for example: in keeping with those forms of topographic inscription and embodiment, the discovery of valuable mineral deposits both in New Guinea and Australia is often interpreted by landowners as further evidence of what they had already known about the places where minerals are found; and negative consequences of mineral extraction — pollution, plant dieback, human illness — are often seen as dysfunctions of a terrestrial organism rather than an inert environment.

In retrospect, that conference can be seen to have coincided with a turn in Jimmy's career path, from an initial phase in which his ethnographic research and writing were mainly directed towards theoretical issues arising from the work of people such as Heidegger, Lacan and Wagner, to an applied-anthropological phase in which Jimmy worked mainly on more 
practical matters such as helping to prepare native title claims in Australia and negotiating landowner agreements with mining companies in Papua New Guinea. So for Jimmy, the name we had chosen for the conference, 'From Myth to Minerals', turned out to be prescient in a way that we could not have foretold.

\section{ACADEMY AND APPLICATION: A LIFE RE-SHAPED? \\ Francesca Merlan \\ The Australian National University}

In 1981-1982, I had a six-month research fellowship in the Department of Anthropology, Research School of Pacific Studies, at the Australian National University, and found myself across the hall from Jimmy, who was writing his dissertation.

Years later in 1994, when he took up the Professorship in Anthropology at the University of Adelaide, Jimmy told me that, having been involved with the heady theorizing of symbolism and obviation, he looked forward to immersing himself in applied anthropology. It wasn't exactly that he spoke of doing good but of doing something that mattered. He worked in native title in Australia from 1998 to the end of his anthropological career. Most of that work was in what he and others called 'settled' Australia, a phrase intended to convey greater disruption of indigenous connection to country in some parts of the continent than others.

His academic and applied interests intersected — collided — in Hindmarsh Island, South Australia. A marina and other tourist facilities had been developed on a part of Hindmarsh Island (at the mouth of the Murray River, across from Adelaide) in the early 1980s. Permission was sought in 1988 for the building of a bridge linking the mainland town of Goolwa to Hindmarsh Island, to foster the expansion of tourism. While surveys and planning 
advice had been that this would not affect any sites of significance, as the bridge-building began in 1994, Doreen Kartinyerri with other Ngarrindjeri women raised the alarm that the building of a bridge would have dire consequences. Hindmarsh Island was said to be associated with what came to be called 'women's business', relating to both human and environmental fertility. The construction of a bridge between mainland and island would form a permanent link between two parts of the landscape whose cosmological efficacy was said to be contingent upon their separation by those who came to be called 'proponent' women. An anthropological report of 1994 supported that point of view, stating that much of the information upon which it relied was secret. Other women who came forward and said they had never heard of this secret tradition came to be known as 'dissident'.

The Hindmarsh Island Bridge Affair — as it became known in the media — raised personal, political, professional and wider anthropological issues that Jimmy was to deal with for years.

First, he argued that the legislative requirements concerning the representation of indigenous culture and society conceal the extent to which this culture and society are themselves elicited by the very form and process of the legislation (Weiner 1999). This, in Hindmarsh, had resulted in a Royal Commission which declared the women's business a 'fabrication'. He did not use (nor I think condone) this term but called the kind of reports and results that came out of a situation like Hindmarsh 'relational'. By that he meant that they were not simply a representation of indigenous society. The legal mechanisms that now surround any development proposal themselves elicit what becomes represented as indigenous.

Second, Jimmy reflected on anthropologists' role under these circumstances. (How) can they tell the difference between what they otherwise record and that which is elicited in the indigenous people's (and their own) relations with developers and governments? The 
reliability of anthropological assessments of indigenous beliefs was being called into question in this case. 'Beliefs', he professed, cannot be verified or even tested anthropologically unless they can be understood as a disposition to act and speak in particular ways - action should be focal, not beliefs. Demands for information, moreover, and contestation in general, can bring about a second kind of tradition, a significant change from the way things would otherwise be (ibid.:208).

Jimmy thought there had been insufficient evidence of the relation between the 'beliefs' of Hindmarsh 'proponent women' and other aspects of their lives (ibid.:207). But his views of the role of anthropologists in such circumstances shifted: they should cease to focus on the 'women's business' as such and investigate the conditions under which this was elicited or made to appear (or to appear in the form it did).

Jimmy's primary concern in that context was with what he saw as the denaturing of anthropology in applied work. A shift gradually occurred in his concept of what anthropology might be in these situations. From the start of his study of Hindmarsh he had noted the imbrication of anthropology in law and in public affairs, and more explicitly articulated a view of anthropology's relation to this in the course of public scrutiny of the Hindmarsh situation.

A commentator of the right-wing Institute of Public Affairs, Ron Brunton, an anthropologist, questioned the 'credibility' of anthropology in Hindmarsh (and in other disputes of the period). In his view, previous development at Hindmarsh had not provoked indigenous resistance; anthropological experts Ronald and Catherine Berndt had not found any women's secret tradition among the Ngarrindjeri in their research on that group (Weiner 1996); the proponent position had been shaped by interested parties and other current influences; and little account had been taken of the position of the dissident women. This had 
produced, in his opinion, a result in which anthropologists' views about development of the bridge were complicit, partial, and an abdication of a wider responsibility to the public.

Jimmy responded (1997b) by rejecting what he saw as Brunton's simplification of anthropologies as Good and Bad. He came back to the importance of examining the social drama of process:

It seems to me that the anthropological way forward in Hindmarsh Island does not consist in a final determination of who was Right and Wrong in this issue, of who the Good and Bad Aborigines were, but of analysing the forces and influences that led the Ngarrindjeri proponents and dissidents as well as their various advocates to assume the perspectives they did and utter the things they said both within and outside of the Royal Commission. (ibid.:8)

Anthropologists in Australia responded in various ways to the Hindmarsh events. Most lamented the intense and hostile scrutiny to which indigenous people were subjected. But, as Deborah Bird Rose (1999) observed, nothing written then about the Ngarrindjeri could be free of the context of the dispute.

Jimmy himself remained, I think, undecided as to how anthropologists might do their work in fraught situations such as Hindmarsh. Jimmy's broader prescription — for anthropologists to analyse the forces of the Hindmarsh situation, and what led proponents and dissidents to do what they did — was, I think, a necessary, but partial recommendation for anthropology as a discipline. To do that alone would remain within the constraints of preformed and dichotomous positions - something for which Jimmy rightly criticized Brunton.

A number of 'sacred sites' disputes like Hindmarsh exploded on the scene as indigenous viewpoints became required in processes of public inquiry and development. The demand for such viewpoints did not mean that they were always adequately portrayed, or welcome, or heeded - in fact, cases like Hindmarsh show the extent to which indigenous viewpoints were cast as anti-development and suspect on the sorts of bases that Brunton adduced. (Similar cases continue — google 2016 Bootu Creek, 2020 Juukan Gorge, etc.) Surely Jimmy 
was right that facile determinations of complex situations are not adequate, and that anthropologists, cognizant of the complexity of situations in which they work, must attempt to apprehend the range of on-going forces as part of their account of social actuality. Brunton is surely right that purpose-focused social research involves questions of public responsibility and accountability. But to whom? And for what? Surely Brunton does not expect unanimity on such questions!

Jimmy went on to conduct many years of consultancy work in heritage and native title. From discussions with him, I know that he came to recognize the requirements of that work as in many ways subject to more intensive scrutiny than research and writing for academic audiences. For this, Hindmarsh was no doubt advance preparation.

\section{A CONJUNCTURAL FIELD \\ Katie Glaskin \\ The University of Western Australia}

In a 2002 paper, Jimmy discussed how his position in relation to his long-term Papua New Guinea fieldwork had begun to change, noting that 'external changes in the world of one's host configures one's perceptions and forces one into these different subject and analytic positions' (Weiner 2002:33). The changes he explored were primarily in relation to Hegeso, a village in Papua New Guinea where he had done his doctoral research with the Foi (see Young, this article). Once 'unmistakably remote even by Papuan New Guinea standards' (ibid.), Jimmy described how Chevron Niugini's discovery of oil west of Lake Kutubu in 1989 had occasioned a significant change for the Foi and their southwest neighbours, the Fasu: "everything suddenly became defined in terms of whether a local clan was or was not a "landowner" within the petroleum development license area (PDL-2)' (ibid.:34). As Jimmy went on to explain, the primary mechanism through which petroleum revenues were to be 
disbursed was via the Incorporated Land Group (ILG), as defined in the Land Group Incorporation Act (1974).

For Australia's Aboriginal and Torres Strait Islander peoples, similar changes were afoot, although they were not always so explicitly development related. The High Court of Australia's decision in the Mabo No. 2 case (Mabo v Queensland (No. 2) [1992] HCA 23) led to the Commonwealth of Australia passing the Native Title Act 1993 (the NTA), a legislative mechanism ostensibly concerned with recognizing Aboriginal and Torres Strait Islander rights to lands and waters. From the earliest days of the NTA, though, it was apparent that the legislation was as much preoccupied with protecting the rights of non-indigenous landholders and the economic potential associated with large-scale resource extraction projects as it was with recognizing the property rights of Australia's own indigenous peoples.

The legal mechanisms for the recognition of customary landholders in both Australia and Papua New Guinea provided the context for one of the two volumes Jimmy and I co-edited, Customary Land Tenure \& Registration in Indigenous Australia and Papua New Guinea: Anthropological Perspectives (Weiner and Glaskin [eds.] 2007, 'the Customary Land Tenure volume'). The Custom: Indigenous Tradition and Law in the Twenty-First Century (Weiner and Glaskin [eds.] 2006, 'the Custom volume') similarly focussed on the legal (and conceptual) basis for the recognition of indigenous land titles, although within a slightly larger array of postcolonial contexts and with less attention to Papua New Guinea. The 2002 Canberra workshop on which this volume was based was motivated by the (then) recent Australian High Court decision in the Yorta Yorta case (Yorta Yorta v Victoria [2002] HCA 58). This decision put the notion of 'traditional laws and customs' at the front and centre of emerging native title jurisprudence in Australia, and prompted an engagement with the broader consequences of relying on such concepts for the legal recognition of indigenous property rights more broadly. The resulting set of papers has a comparative scope that 
included a consideration of adat in Indonesia and the 'integral to a distinctive culture' test in Canada.

The Customary Land Tenure volume took Australia and Papua New Guinea as its particular comparative focus. Many of the papers in the volume, though not all, derived from a workshop Laurence Goldman and John Bradley convened in Brisbane in 2000. Like the Custom volume, a central theme of the Customary Land Tenure volume is that the legislative processes that purport to recognise pre-existing indigenous land entitlements actively configure the customary in particular forms: this meant, as Jimmy put it, one could not assume that 'the internal affairs and composition of landowning social units are both practically and ontologically prior to their external relations' (Weiner and Glaskin 2007:6). Of particular interest in this volume is the relationship between legislation that provides for the recognition of indigenous rights to land and the constitution and incorporation of landowning groups: contributors emphasised that such bounded, incorporated entities are contrary to the realities of indigenous social life.

Both volumes interrogated the idea of 'custom' (kastom) or 'tradition' (in the Australian context) as the basis for the recognition of indigenous relations to land. Both saw engagement with national legislation as eliciting the customary in particular forms capable of recognition by the state; both saw the resulting (required) incorporation of indigenous landowner groups as enforcing a kind of stability and intelligibility largely incommensurable with the lifeworlds of those to whom such prescriptions were subsequently applied, but which provided 'legibility' (Scott 1998) to the state and to developers. And both volumes insisted that indigenous lifeworlds need to be understood as existing within a 'conjunctural field' (Weiner and Glaskin 2006:5) in which

the analysis of the transformation of the customary into the justiciable [begins] not from the perspective that colonialism represents a break in tradition, but from the perspective that the laws, practices and customs of both the Western nation state and indigenous people embedded in it are developing and evolving out of each other. (ibid.:5) 
In other words, 'in places such as Papua New Guinea and Australia, "customary law” has been a product of the colonial encounter' (ibid.:4).

Writing about Gluckman's (1940) famous 'bridge paper', Cocks (2001:740) argues that his methodological innovation (in the form of 'situational analysis' or the 'extended case method') and its important critique of segregationist policy are 'intimately connected'. The contributions in these volumes likewise intimately connected case studies based on extended fieldwork with political critique and theoretical reflection, contributions informed by both applied and academic anthropological engagement.

Jimmy wrote substantial reports for at least 25 Australian native title claims and peer reviewed anthropological reports in another nine native titles cases. Jimmy’s final anthropological contribution was made working for the applicants in the Bindunbur native title claim (Manado v State of Western Australia [2017] FCA 1367), successfully determined by the Federal Court of Australia in 2017, an outcome with which he was well pleased.

CONSULTANCY CONNUNDRUMS 2005-2014

Laurence Goldman

The University of Queensland

Beneath the 'clear web' of monographs, theses, journal articles, patrol reports and bequeathed notes etc., there exists for researchers of Papua New Guinea cultures a 'deep web' of unpublished and hitherto unheralded studies. Access to this resource constituted in part by social mapping, social impact, Incorporated Land Groups (ILG) and land/landowner reports - is protected and encumbered by confidentiality clauses in consultancy agreements detailing rights of ownership and use of intellectual property (IP). 
Between 2005 and 2014, Jimmy Weiner conducted a series of fieldwork trips for the ExxonMobil Papua New Guinea (PNG) LNG Project ${ }^{4}$ across Hela, Southern Highlands, Gulf and Western provinces. These ventures produced seven ${ }^{5}$ book-length studies narratively chained and with threads to preceding but equally hidden regional studies. Whilst the primary goal was to assist in identifying 'project area landowners' in accordance with prevailing land and resource legislation, the report contents ranged expertly across cultural heritage, migration, history, language, social structure and change. Jimmy's avowed objective in this oeuvre was to build 'social literacy' in his readership and in a manner that reflected the primacy of anthropology as a clarifying lens.

The enabling advantages of GIS, handheld GPS and Exxon's logistics system allowing Jimmy to traverse cultures and vast landscapes with both speed and ease - did not mitigate the fact that he worked in a politically charged cauldron of development. Few escape such commissions of landowner and boundary identification without being a catalyst for disaffection, dispossession and disenfranchisement. Jimmy ably bridged those sectional interests of hosts, developer and government agencies whilst simultaneously avoiding the pitfalls of time-compromised data strip-mining. His works were neither criticised nor attracted controversy. What we inherit is a set of anthropologically nuanced reports, baselines, photographs and culturally sensitive materials that in breadth, quality and insight is nonpareil.

From the brief selection of statements below we surely gain a flavour of just some of the profound themes with which Jimmy engaged.

- 'This tension between the benefits of widespread relatedness on the one hand and the desire to maintain autonomy on the other pervades all levels of inter-clan and inter-village alliance and relationship' (2005b:39) — discussing how same-named social units regarded their claims on and obligations to each other in a resource project context.

- 'Somewhere between the village and the hypostasized language-territorial "tribe" probably lie the emergent units of contemporary modern community and economy' (2005b:52) - discussing the emergence of 'tribal' politics in the region. 
- "Custom" is in most respects an illusion pursued by those who refuse to countenance that PNG custom is a more or less direct product and effect of the colonial presence, not an adamantine self-contained system that preceded it and continues to set itself against it. For "custom" could only become visible when placed against a counterpoised system of "Law" such as underwrote the Anglo-Australian colonial social system' (2005b:96) - discussing the fluidity of land transfers in the pre-contact era.

- 'The whole notion of "the village" as an enclosed site of social life is out of date and has been for a long time' (2005a:110) — discussing modernity and the geographical spread of related and previously co-residential people to rural and urban locales.

- 'The validity of local idioms and not the preservation of anthropological terminology is the issue at stake in this exercise' (2005b:41) - discussing newly adopted and introduced conventions for land claiming units.

- 'Erosion of customary life will reduce the ability of local people to respond to both challenge and opportunity and will make violent response to frustrated demands more inevitable. The long-term monitoring of what could be called the "social health" of customary village life needs some attention'. (2006:108)

Weiner tells us culture resists legal codification in the same way identifying groupto-ground grids resists the application of an algorithm. He belabours the point that snapshot seekers of 'frozen landscapes' and certitude are doomed to failure, which in turn generated a long-term engagement with and intense scrutiny of the flaws and inequities in the ILG framework as a vehicle for benefit distribution. These themes were pursued throughout his career with a rare conviction and demonstrated a granularity that at times exceeded levels found in the published materials.

Harnessing field skills garnered from decades of deep immersion, it is as if Weiner's imbricated interests in law, myth, naming systems, poetics and place coalesced at their acme in a Talmudic untangling of the Gobe ${ }^{6}$ social landscape (2005b), exercised as always through Roy Wagner's Gopro. Deciphering a decade-long land dispute required triangulating and navigating volumes of Lands Title Commissions submissions, early patrol reports, developer agency baselines and fieldwork data. Historical migration patterns had produced a melting pot of multi-ethnic populations (Polopa, Kewa, Kasere) whose social groups presented as named confederacies confounding any attempt to demarcate ethnic-specific 'clans'. These were units underwritten by 'principles of physical 
proximity and perceived propinquity'. Using the scaffold of a detailed chronology, the report unfolds like a sequenced 'who done it' novel culminating in both a forceful and brilliant demonstration of the way names encode, encapsulate and (in Jimmy's favourite term) 'enhouse' keychain access to identities. This was less a recitation of an artist's skill set and more an evocation of this anthropologist's spirit.

These reports present the workings of a unique Melanesian savant whose pursuit of his professional calling tethered him to grounding his enlightenment in imaginative storytelling, but never in a 'forever Foi' way. He drew from multiple field sites and indeed constantly reminded us that developer, consultant, researcher and indigenous actor were all dramatis personae on the same stage. Many others including his peers may have traversed the same bush tracks but few did it with the audacity to anchor his non-professional readership to the anthropological life-raft. This is nowhere better demonstrated than in his inclusion of discursive report sections entitled 'Anthropology: The Marked View from the Bottom and from the Top' (2005a:104) and 'The Normalisation of Cargo Mythology' (2005b:61) in an industry social mapping and landowner identification (SMLI) report! But Jimmy would be the first to tell you that nobody said, and nobody should assume, science is easy reading; this very much marked the 'point of difference' about his ventures.

\section{CONTEMPLATION AT THE HEART OF THE PEARL SHELL Emma Gilberthrope University of East Anglia}

The first time I met Jaimie Pearl Bloom, I had taken a moment out of fieldwork to visit the Chevron Niugini company camp, some three hours' drive from where I was based in the Hekikio valley. As I entered the community relations building to send home the requisite fax, 
I noticed a new face sat behind a desk in an otherwise empty office. When I realised who it was - the author of a rich and contemplative literature on the Foi language group — I was, at first, overjoyed to see them, and then a little surprised. I had devoured everything Jaimie had written long before stepping foot in Papua New Guinea, so meeting the author of that work was nothing less than thrilling.

I was in the early stages of my PhD fieldwork with the Fasu language group, the Foi's immediate neighbours, and it was through Jaimie's work that I had constructed a picture of the place I now found myself in. The Lost Drum, The Empty Place, The Heart of the Pearl Shell - hypnotic titles that drew me into a captivating world of poetry and songs, of metaphor and meaning, of movement, pathways and flows, and of ghosts and dreams and spells. Jaimie's broad opus of work speaks of personhood and pluralities, beautifully and poetically confronting the limitations embedded in Western notions of 'self' and connectivity to the animate and inanimate other.

It was this deeply philosophical analysis of 'the productive relationships between humans and their territory' (Weiner 1988:23) that caused my initial jubilation at meeting Jaimie to turn into surprise. Jaimie was there, she said, as 'a Consultant'. Her job? To audit Foi Incorporated Land Groups (Weiner 2000). This work would continue for many years, resulting in eight consultancy reports (e.g., Weiner 2005) that mapped and identified landowners as members of an Incorporated Land Group (ILG).

The ILG is a basic, externally devised system of structured ownership that defines a possessive, rather than a productive, relationship between individuals [males] and territory. The absolute nature of this structure, however, neither comfortably nor conveniently fits within the intricate flows and movement of Papua New Guinea sociality that Jaimie so perfectly describes. In the introduction to Mountain Papuans, Jaimie writes:

The manner in which Mountain Papuan peoples ... depict genealogical relationships as spatial ones between place names reminds us that land, of course, is not merely an inert 
resource with respect to social relations, but a subjectively transformed medium, as alive and as fluid as pearl shells, and as constitutive of social relations as pearl shells. (Weiner 1988:23)

How, I wondered, could someone who writes about imaginaries of movement and flow at the heart of social worlds, about pathways, spatial vacuums and inhabited empty spaces, be tasked with auditing ownership?

Maybe Jaimie wondered the same thing herself. On that day, when we met in the Chevron community relations building, we were both wearing our obligatory Chevron identity badges. She looked at mine, which said 'Anthropologist' under my name and said, 'Oh you get to have "anthropologist" on your badge. Look what they put on mine!' And as she said it, she lifted her badge up for me to see. I leant in and noticed that in place of 'Anthropologist' was the descriptor 'Consultant'.

For many anthropologists, particularly those working in areas as remote as internal Papua New Guinea, being 'in the field' is a momentary release from the restrictions and limitations of the Western world and a dramatic departure from the academic environment in which we otherwise find ourselves; a retreat from its absolute structures, its inbred hierarchies and subtle awakenings of power. I re-read Jaimie's work before writing this piece, revisiting her philosophical musings about how we experience and orient ourselves in the world and adjust to fit into it, and I thought that just perhaps Jaimie, like many of us, had spent her time in the field searching for something far more profound than the delicacies of Foi lived experience. Just perhaps, I thought, she was searching for bigger answers to bigger questions. What it is to be caught in life's relentless current. Or trapped and rendered motionless in a stagnant pool at its edge.

To finish, I reproduce the M.D. Herter Norton translation of Rainer Maria Rilke's Sonnets to Orpheus, no. 19, which appears at the beginning of The Empty Place. For me, it sums up Jaimie quite nicely: 
Even though the world keeps changing

quickly as cloud-shapes,

all things perfected fall

home to the age-old.

Over the changing and passing,

wider and freer,

still lasts your leading-song,

god with the lyre.

Not understood are the sufferings.

Neither has love been learned,

and what removes us in death

is not unveiled.

Only song over the land

hallows and celebrates.

\section{NOTES}

1.Our correspondence will be deposited in the Pacific Archives under my name, ref. ANUA $3651970-1471$.

2.Wagner's theory is spelled out in detail in Lethal Speech: Daribi Myth as Symbolic

Obviation (1978). See also Leach's contribution.

3.The ANU research group 'Gender relations in the Southwestern Pacific' was organized by

Roger Keesing, Marie Reay and Michael Young, and met over 1983-1984.

4. The PNG LNG project is the largest capital investment petroleum project in Papua New

Guinea. Gas is extracted from multiple fields in Hela province and transported via pipeline to a processing plant located on the south coast near Port Moresby.

5. See References.

6. Gobe is the name of a petroleum field located in the Southern Highlands and Gulf

provinces as well as a term used for the area between Kantobo and Kaiam in that province. 


\section{REFERENCES}

BRUNTON, R. 1996. The Hindmarsh Island Bridge and the Credibility of Australian Anthropology. Anthropology Today 12(4):2-7.

COCKS, P. 2001. Max Gluckman and the critique of segregation in South African Anthropology, 1921-1940. Journal of Southern African Studies 27(4):739-756.

CROOK, T. 2007 Anthropological Knowledge, Secrecy and Bolivip, Papua New Guinea: Exchanging Skin. Oxford and New York: Oxford University Press, British Academy Postdoctoral Fellowship Monograph series.

GLUCKMAN, M. 1940. Analysis of a Social Situation in Modern Zululand. Bantu Studies 14:1-30.

GREGOR, T., and D. TUZIN (eds.). 2001. Gender in Amazonia and Melanesia: An Exploration of the Comparative Method. Berkeley: University of California Press.

HITCHCOCK, G. and J. WEINER. 2014. Full-Scale Social Mapping \& Landowner Identification Study of PRL3 P'nyang Project (Southern Pipeline). 111 pp. Esso PNG P'nyang Limited.

INGOLD, T. 2011. Being Alive: Essays on Movement, Knowledge and Description. Abingdon: Routledge.

KNAUFT, B. 1993. South Coast New Guinea Cultures: History, Comparison, Dialectic. Cambridge: Cambridge University Press.

KOLIG, E. 1987. The Noonkanbah Story: Profile of an Aboriginal Community in Western Australia. Dunedin: University of Otago Press.

LAKOFF, G. and M. JOHNSON. 1980. Metaphors We Live By. Chicago: University of Chicago Press.

LAMBEK, M., and A. STRATHERN. 1998. Bodies and Persons: Comparative Perspectives from Africa and Melanesia. Cambridge: Cambridge University Press.

MERLAN, F. 1991. The limits of cultural constructionism: The case of Coronation Hill. Oceania 61:1-12.

MUNN, N. 1969. The effectiveness of symbols in Murngin rite and myth. In Robert F. Spencer (ed.), Forms of Symbolic Action: Proceedings of the 1969 Meeting of the American Ethnological Society, pp. 178-207. Seattle: University of Washington Press.

NILES, D. 2015. Introduction: Foi Songs and the Performance, Publication, and Poetry of Papua

New Guinea Sung Traditions. In J.W. Weiner and D. Niles, Songs of the Empty Place: The Memorial Poetry of the Foi of the Southern Highlands Province, Papua New Guinea, pp. xv-xlix. Canberra: ANU Press.

ROSE, D.B. 1999. Book Review - Ngarrindjeri Wurruwarrin: a world that is, was, and will be. IndigLawB 10; 4(17) Indigenous Law Bulletin 22. Online: http://classic.austlii.edu.au/au/journals/IndigLawB/1999/10.html\#Heading1.

RUMSEY, A. 1994. The dreaming, human agency and inscriptive practice. Oceania 65:116130.

RUMSEY, A., and J.F. Weiner (eds.). 2001a. Emplaced Myth: Space, Narrative, and Knowledge in Aboriginal Australia and Papua New Guinea. Honolulu: University of Hawai'i Press.

RUMSEY, A., and J.F. Weiner (eds.). 2001b. Mining and Indigenous Lifeworlds in Australia and Papua New Guinea. Bathurst: Crawford House Publishing (republished in 2004 by Sean Kingston Publishing, Wantage, Oxon, UK). 
SCOTT, J. 1998. Seeing Like a State: How Certain Schemes to Improve the Human Condition Have Failed. New Haven: Yale University Press.

WAGNER, R. 1972. Habu: The Innovation of Meaning in Daribi Religion. Chicago: University of Chicago Press.

1978. Lethal Speech: Daribi Myth as Symbolic Obviation. Ithaca: Cornell University Press.

1981. The Invention of Culture. Revised and expanded edition. Chicago: University of Chicago Press.

WEINER, J.F. 1984. Sunset and flowers: The sexual dimension of Foi spatial orientation. Journal of Anthropological Research 40:577-588.

1985. The treachery of co-wives: The mythical origin of mediating food items in Foi. Journal de la Société des Océanistes. 41:39-50.

1986. Blood and skin: The structural implications of sorcery and procreation beliefs among the Foi of Papua New Guinea. Ethnos 51:71-87.

1988. The Heart of the Pearl Shell: The Mythological Dimension of Foi Sociality. Berkeley:

University of California Press.

1991. The Empty Place: Poetry, Space, and Being among the Foi of Papua New Guinea. Bloomington: Indiana University Press.

1992. Anthropology Contra Heidegger: Part I: Anthropology's Nihilism. Critique of Anthropology 12(1): 75-90.

1993. Anthropology Contra Heidegger: Part II: The Limit of Relationship. Critique of Anthropology 13(3): 285-301.

1994. The origin of petroleum at Lake Kutubu. Cultural Anthropology 9:37-57.

1995. The Lost Drum: The Myth of Sexuality in Papua New Guinea and Beyond. Madison: University of Wisconsin Press.

1997a. Televisualist Anthropology: Representation, Aesthetics, Politics. Current Anthropology, 38(2):197-235

1997b. 'Bad Aboriginal' Anthropology: A Reply to Ron Brunton. Anthropology Today 13(4):5-8.

1999. Culture in a Sealed Envelope: The Concealment of Australian Aboriginal Heritage and Tradition in the Hindmarsh Island Bridge Affair. The Journal of the Royal Anthropological Institute 5(2):193-210.

2000. Audit of Foe Incorporated Land Groups: Report and Analysis. Submitted to the PNG Department of Petroleum and Energy and Chevron Niugini Ltd.

2001. Tree Leaf Talk: A Heideggerian Anthropology. Oxford: Berg.

2002. Assuming the Mercenary Position: Changing Perspectives in Long-Term Fieldwork in Papua New Guinea. The Asia Pacific Journal of Anthropology 3(2):33-43. 2005a. Full-Scale Social Mapping \& Landowner Identification Study of Kutubu PDL2, PNG Gas Pipeline. 113 pp. Oil Search Limited.

2005b. Full-Scale Social Mapping \& Landowner Identification Study of Kantobo to Kaiam PNG Gas Pipeline. 146 pp. Esso Highlands Limited.

2006. Full-Scale Social Mapping \& Landowner Identification Study Kaiam-KopiOmati-Goaribari Proposed Gas Pipeline Route.120 pp. Esso Highlands Limited.

2008. Full-Scale Social Mapping \& Landowner Identification Study of Portion 152 Environs. 82 pp. Esso Highlands Limited.

2011. Full-Scale Social Mapping \& Landowner Identification Study Kido Village. 53 pp. Esso Highlands Limited.

WEINER, J.F. and K. Glaskin. 2006. 'Introduction: The (Re-)Invention of Indigenous Laws and Customs'. In J. Weiner and K. Glaskin (eds.), Custom: Indigenous Tradition 
and Law in the Twenty-First Century. The Asia and Pacific Journal of Anthropology 7(1):1-13.

WEINER, J. and K. GLASKIN (eds.). 2006. Custom: Indigenous Tradition and Law in the Twenty-First Century. The Asia and Pacific Journal of Anthropology 7(1):1-104.

WEINER, J.F. and K. Glaskin. 2007. Customary Land Tenure and Registration in Papua New Guinea and Australia. In J.F. Weiner and K. Glaskin (eds.), Customary Land Tenure \& Registration in Indigenous Australia and Papua New Guinea: Anthropological Perspectives, pp. 1-14. Canberra: ANU E Press.

WEINER, J.F. and K. Glaskin (eds.). 2007. Customary Land Tenure \& Registration in Indigenous Australia and Papua New Guinea: Anthropological Perspectives. Canberra: ANU E Press.

WEINER, J. and L. GOLDMAN. 2009. Full-Scale Social Mapping \& Landowner Identification Study Pipeline Right-of-Way Sections in PPL233 and PPL219. 112 pp. Esso Highlands Limited.

WEINER, J. and D. NILES 2015. Songs of the Empty Place: The Memorial Poetry of the Foi of the Southern Highlands Province of Papua New Guinea. Canberra: ANU Press. 